\title{
5 A Networked Humanity
}

\begin{abstract}
This chapter examines the discourse of film as universal language in relation to the narrative figure of the network. I contend that D. W. Griffith's Intolerance (2016) constitutes an illustrious precursor of the global network narrative genre. This analysis is then substantiated by my reading of Alejandro González Iñárritu's Babel (2006), a film that bears remarkable resemblance with Intolerance in its formulation of universality via a multinarrative textual design and focus on suffering as the lingua franca of humanity. The chapter closes with a consideration of Eduardo Williams's The Human Surge (2016), a film in which totalising ideas of humanity and globality are also mapped on to a networked narrative configuration. Here, however, miserabilism plays no part and the network is broadened into a wider web that includes the physical Earth itself.
\end{abstract}

Keywords: network narrative, universalism, humanity, Intolerance, Babel, The Human Surge

Ethics feeds too much on Evil and the Other not to take silent pleasure in seeing them close up. Alain Badiou

In his book Networking the World, 1794-200o (2000), Armand Mattelart traces the genealogy of the network as a mode of international social organisation and integration since the turn of the eighteenth century. He notes: 'Networks, a leading symbol of progress, have also made their incursion into utopian thinking. The communication network is an eternal promise symbolizing a world that is better because it is united. From road and rail to information highways, this belief has been revived with each technological generation.'

1 Armand Mattelart, Networking the World, 1794-20oo, trans. Liz Carey-Libbrecht and James A. Cohen (Minneapolis and London: University of Minnesota Press, 200o), viii.

de Luca, T. Planetary Cinema. Film, Media and the Earth. Amsterdam: Amsterdam University Press, 2022 DOI: 10.5117/9789463729628_CHO5 
In short, the "dream of reestablishing the pre-Babel "great human family" is present throughout the history of the imaginary of communication networks'. ${ }^{2}$ Yet, as Mattelart hastens to add, 'networks have never ceased to be at the center of struggles for control of the world', motivated by interests as wide ranging and dubious as 'the universalism of a predestined civilization' and 'the pragmatism of the corporation'. ${ }^{3}$ Whether in idealist or imperialist guises, networks are therefore inseparable from discourses of universalism which are themselves ridden with ideological contradictions.

The emergence of cinema was a milestone in the networking imaginary and accordingly duly lauded on the basis of its universalism. Mattelart continues: 'Cinema was to open the way for the mythology of universal communication in the "era of images", which became another symbol of the end of inequality between classes, groups, and nations'. ${ }^{4}$ Film was hailed as a new language: one that was universal because it was visual; or, to cite one commentator, writing in 1914: 'Eye language is universal and direct - seeing is believing.'. Another writer exclaimed: "The art of the film, alone, is unlimited and free. In sight we are all equal. The civilised man and the savage both have eyes and can see with them,. ${ }^{6}$ And yet another critic enthused: 'Love of pictures is engrained in us, whatever our color, race, or age [...] Oratory has impressed thousands, the Press hundreds of thousands, the moving picture millions, and that in a way the others do not, reaching out amongst all races, stirring all grades from the old to the young.7

As some of these statements already suggest, however, the universality of cinema, much like that of the galleries of humanity we explored in the last chapter, presupposed a segregation of humanity into the 'civilised' and the 'savage'. Film's universalism in this context was just another name for its purported 'civilising mission', as 'simple natives', one writer commented, could learn 'from the pictures how the white man lives in his home. ${ }^{8}$ Just as importantly, whereas cinema was seen as 'decidedly international in all its aspects [...] bounded neither by nationality nor prejudice', to cite another contemporaneous statement, there was no question that the nascent film companies, mostly

3 Ibid., vii-viii.

4 Ibid., 19.

5 Joseph Best, 'Seeing the World by the Cinema', Pathé Cinema Journal 39:II (25 June 1914), 39.

6 'The Cinematograph Industry Round the World: Interview with Mr. A. C. Bromhead', The Bioscope 355 (31 July 1913), 335.

7 'The Lure of the Picture', Moving Picture World, reprinted in 'The World's Press', The Bioscope 211 (27 October 1910), 41.

8 Margaret I. Macdonald, 'The Trend of the Times', The Bioscope 256 (7 September 1911), 497. 
based in Europe (especially France) and North America, hoped to benefit from this internationalism less as a means of establishing fraternal bonds between fellow humans than as a way to conquer the world market.$^{9}$

In these early-cinema discourses and perceptions, universalism often revolved around the non-fiction travel film, or travelogue, which simultaneously showed and toured the world. The links between such films, or the places they depicted, were established either in the spectator's (and commentator's) mind, or at most flimsily forged by miscellaneous early cinema programmes organised under the theme of global travel, as we saw in chapter 3 . Yet there was one film, released in 1916, which, directly inspired by the universal-language idea, explicitly attempted to create links, via editing, between different space-time worlds so as to concretise the idea of a global networked humanity. That film was D.W. Griffith's Intolerance, which, as this chapter will show, condensed both in its textual constitution and production history the contradictions and limitations of cinematic universalism outlined thus far.

As a canonical film in its own right, Intolerance has received voluminous critical attention, not least in relation to the discourse of film as a universal language. Here I hope to extend this important work by showing that the film's universalism is inseparable from a networked conception of the globe. A foundational figure when it comes to the application of editing as an expressive narrative device, Griffith's use of montage in Intolerance is revealing of a desire to make visible the material and immaterial links connecting humanity since times immemorial and across a global stage. Unlike the early photographs, films and projects examined in most chapters of this book, Intolerance's claims of visible disclosure are therefore less dependent upon the recorded image's indexical properties. This is certainly a fiction film, mostly shot in purposefully built studio sets, and one that, indeed, freely reconstructed historical events. But, while existing in a different guise, an understanding of the film medium as a tool of visibility is still evident here, although crystallised around the notion of cinematic linkage, that is, the interplay between different images that can disclose or reiterate connections across time and space. In this context, as I hope to show, Intolerance's figuration of a global network is not only established on the metaphysical level of its diegesis, as afforded by its (in)famous quadripartite, back-and-forth structure, but also quite literally in its modern narrative via recourse to images and tropes of railway, motorway and telecommunication networks. 
More specifically, I wish to argue, Intolerance constitutes an illustrious precursor of the contemporary 'network narrative', defined by David Bordwell 'as the dominant principle of offbeat storytelling' since the early 1990s, in tune with 'a deepening awareness of human connectivity on a global scale'. ${ }^{10}$ Bordwell's terminological choice is indebted to 'a more formal theory of networks and "small worlds"' that emerged in the 1950s and 1960s, and which became popularised through 'the notion of "six degrees of separation"' and 'the butterfly effect'. ${ }^{11}$ The idea that we live in a 'network society', made of 'networks in all the key dimensions of social organization and social practice', has also been advanced by Manuel Castells. ${ }^{12}$ In the network film, this configuration often translates into a broadening of the film's geographical parameters, which can encompass: cities, be it the Paris of Les Parisiens (Claude Lelouch, 2004) or the London of Wonderland (Michael Winterbottom, 1999); countries, such as the China of $A$ Touch of Sin (Tian zhu ding, Jia Zhangke, 2012); and indeed the world itself as characters navigate across countries and continents. Examples of the latter, which I will call here 'the global network narrative', include: Traffic (Steven Soderbergh, 2000), Syriana (Stephen Gaghan, 2005), The Edge of Heaven (Aufder Anderen Seite, Faith Akin, 2007), and most remarkably, the suggestively titled Mammoth (Lukas Moodysson, 2009), 36o (Fernando Meirelles, 2011) and Babel (Alejandro González Iñárritu, 2006).

While arguing for a reassessment of Intolerance's universalism via the concept of the network, the contemporary focus of this chapter is, conversely, motivated by a quest to explore how the network film has rekindled the idea of film as a universal language in our time. Nowhere is this more visible than in Babel, which, as its title suggests and my analysis will demonstrate, channels the global network into the discourse of a universal language. Generally understood in terms of chance encounters and 'intertwining plotlines' that 'affect one another to some degree', to cite Bordwell again,

10 David Bordwell, Poetics of Cinema (New York: Routledge, 2008), 191-192; 198.

11 Ibid., 198. Although I will stick to 'network narrative', it must be noted that the genre has given rise to a number of critical terms, including: 'hyperlink', 'mosaic', 'multi-protagonist', 'complex' and 'multiplex'. On 'hyperlink' films, see Alissa Quart, 'Networked', Film Comment 41:4 (2006): 48-51. On the 'mosaic' film, see Patricia Pisters, 'The Mosaic Film: Nomadic Style and Politics in Transnational Media Culture' in Mieke Bal and Miguel Á. Hernández-Navarro (eds.) Art and Visibility in Migratory Culture: Conflict, Resistance, and Agency (New York: Rodopi, 2011), 175-190. On the 'multi-protagonist' film, see Maria del Mar Azcona, The Multi-Protagonist Film (Oxford: Wiley-Blackwell, 2010). On 'complex narratives', see Peter F. Parshall, Altman and After: Multiple Narratives in Film (Plymouth: Scarecrow, 2012). On 'multiplex cinema', see Hamid Nacify, 'Multiplicity and Multiplexing in Today's Cinema: Diasporic Cinema, Art Cinema, and Mainstream Cinema', Journal of Media Practice 1 (2010): 11-20.

12 Manuel Castells, The Rise of the Network Society (Malden, MA: Wiley-Blackwell, 2010), xviii. 
the network narrative is often traced back to films such as Grand Hotel (Edmund Goulding, 1933) and directors such as Robert Altman. ${ }^{3}$ I hope to demonstrate that even if Intolerance does not entirely fit into this description, to examine it alongside $\mathrm{Babel}$ makes sense because they are both the earnest products of a sentimental humanism that relies on comparative fatalism and human suffering, which in both films is moreover translated into graphic close-ups of bodies and faces in pain. By charting the continuities between these two films' take on the human with recourse to the philosophical theories of Richard Rorty, Alain Badiou and Hannah Arendt, my hope is to demonstrate the tenacity of the trope of the universal language as it has manifested itself at two crucial moments in film history, while evaluating its effectiveness and fault lines as both an aesthetics and a politics.

In the last section I turn to a more recent, small-budget film: Eduardo Williams's The Human Surge (El auge del humano, 2016), which, I contend, provides a meaningful counterpoint against which to compare the networked universalism of Intolerance and Babel. This is, first, because the film eschews human miserabilism in its networking of the planet, favouring instead sensory snapshots of everyday life in all its indeterminacies and hardships but also pleasures. Second, whereas the film critically thematises the network's capitalist subservience and triumphalist discourses on the Internet as a new form of universal communication, it equally shows the world, or the Earth, to be crisscrossed by other networks that escape and exceed the human, thereby injecting a much-needed ecological and material substratum into our global network society.

\section{'One Common Flood of Humanity'}

How could someone who had directed a blatantly racist film follow it up with another that claimed to speak on behalf of a universal humanity? The answer to this question is not as straightforward as it may seem but the fact is that Intolerance's conception and execution is intimately bound up with The Birth of a Nation (1915). Controversial though it was, the latter was a hit upon its release,

13 David Bordwell, 'Lessons from Babel', Observations on Film Art (27 November 2006), http:// www.davidbordwell.net/blog/2006/11/27/lessons-from-babel/ (last accessed 9 December 2016). On the lineages of the multinarrative film, see Bordwell, Poetics of Cinema, 194-197; Azcona, The Multi-Protagonist Film, 46-79; Parshall, Altman and After, 21-44. It must also be noted that Pisters, Azcona and Parshall do acknowledge Intolerance as a potential precursor of the multinarrative film, though they do so tentatively and in passing. See Pisters, 'The Mosaic Film', 175-176; Azcona, The Multi-Protagonist Film, 9; Parshall, Altman and After, 14. 
making Griffith rethink the dimensions of his next film, which began to appear too small in comparison. ${ }^{14}$ The director had already filmed Intolerance's Modern Story, until then a single-narrative feature provisionally entitled The Mother and the Law, during the editing of The Birth of a Nation. Only later did Griffith come up with the idea of adding three more stories whose historical and religious weight were meant to evoke the "European "historical-spectacle" films' he so admired, including Quo Vadis (Enrico Guazzoni, 1912) and Cabiria (Giovanni Pastrone, 1914). ${ }^{15}$ The idea to organise the four stories around the thematic axis of 'intolerance' was also a rebuke to what Griffith considered the curtailment of artistic freedom by the Motion Picture Producers and Distributors of America (MPPDA). That is, Intolerance was never meant to rectify The Birth of a Nation's racism but, on the contrary, arose out of Griffith's belief that he was being dishonestly persecuted by reformists.

In light of this, it is not difficult to agree with Slavoj Žižek, for whom Griffith's cry against intolerance 'is much closer to today's fundamentalists decrying the "politically correct" defence of universal rights of women as "intolerant" towards their specific way of life. ${ }^{16}$ Ryan Jay Friedman has similarly noted that Intolerance's 'conceptual origins in Griffith's racism - not to mention his fatuous insistence on viewing himself as the victim of hatred - invalidates the film's putative humanitarian ideology, rendering it nonsensical from the start. ${ }^{17}$ On the other hand, Griffith did earnestly believe in his mission to fulfill the promise that cinema was the 'universal language that had been predicted in the Bible, which was to make all men brothers because they would understand each other', as once recounted by actress Lillian Gish. ${ }^{18}$ Intolerance is therefore inseparable from the transnational discourse of film as a universal language against which its aims and claims must be accordingly assessed.

As Miriam Hansen has shown, Intolerance was one of the first attempts to 'put the universal language proposition into textual practice' through recourse to a multinarrative structure. ${ }^{19}$ Hansen's authoritative analysis of

14 Melvyn Stokes, D.W. Griffith's The Birth of a Nation: a History of the Most Controversial Motion Picture of All Time (New York: Oxford University Press, 2007), 263.

15 Ibid., 78.

16 Slavoj Žižek, 'Against an Ideology of Human Rights' in Kate E. Tunstall (ed.) Displacement, Asylum, Migration: The Oxford Amnesty Lectures 2004 (Oxford: Oxford University Press, 2006), $56-85 ; 63-64$.

17 Ryan Jay Friedman, The Movies as a World Force: American Silent Cinema and the Utopian Imagination (New Brunswick, NJ: Rutgers University Press, 2019), 82.

18 Lillian Gish, with Ann Pinchot, The Movies, Mr. Griffith, and Me (Englewood Cliffs: Prentice Hall, 1973), 6 o.

19 Miriam Hansen, Babel and Babylon: Spectatorship in American Silent Film (Cambridge, MA, and London: Harvard University Press, 1991), 186. 
the film, originally published in 1991, is both tacitly and overtly anachronistic. The former because it necessitates as its negative counterpart the theoretical notion of a classical cinema formulated many decades later against which the unusual narrative design of Intolerance can be positively assessed. The latter because, as she puts it, 'one cannot avoid reading Intolerance from a perspective of the present, along the vanishing lines of a tradition of alternative filmmaking that includes names like Dziga Vertov, Sergei Eisenstein, Jean-Luc Godard, Alexander Kluge and Chantal Akerman. ${ }^{20}$ In this section, my analysis will also be informed by a certain degree of anachronism, though my contention is that Intolerance appears as a fascinating precursor of the global network film examined in the next section in relation to Babel. This reading, I hope to show, finds substantiation not only when we look at Intolerance's quadripartite structure, which revolves around fatalism and human suffering, but also when we consider its picturing of a networked society as the end of the circularity of history in its modern narrative. First, however, an exploration of some contemporaneous discourses of universalism is in order.

We saw earlier that the idea of film as a universal language shares its genesis with the new medium, ubiquitously featuring in the general press and trade magazines. From the early 1910s, universalism worked its way into early film theories developed in countries as disparate as Italy, Germany, France and the US. ${ }^{21}$ Ricciotto Canudo's 1911 essay 'The Birth of a Sixth Art' offers a programmatic condensation of film's celebrated universality. It notes how cinema enacts a 'symbolic destruction of distances' and takes the 'spectacle of distant, enjoyable, moving and instructive things' to even 'the smallest human settlement'. It then cherishes film's appeal 'to all social classes, from the lowest and least educated to the most intellectual' in terms of a site-specific community in the cinema that evokes a worldwide community of spectators. ${ }^{22}$ Similar ideas were reprised a few years later by the French film critic and director Louis Delluc, for whom cinema touched 'the unanimity of the masses' in a manner analogous to Greek theatre, which 'had to satisfy all classes of society'. ${ }^{23}$ Delluc continued: 'The semicircle in which the cinema spectators are brought together encompasses the whole

20 Ibid., 132.

21 See Mattias Frey, 'Cultural Problems of Classical Film Theory: Béla Balázs, "Universal Language" and the Birth of National Cinema', Screen 51:4 (2010): 324-340.

22 Ricciotto Canudo, 'The Birth of a Sixth Art (1911)' in Richard Abel (ed.) French Film Theory and Criticism, 1907-1929 (Princeton, NJ: Princeton University Press, 1988), 58-65; 60, 65.

23 Louis Delluc, 'From Orestes to Rio Jim (1921)', French Film Theory, 255-257; 257; Louis Delluc, 'The Crowd (1918)', French Film Theory, 159-164; 162. 
world. The most separated and diverse human beings attend the same film at the same time throughout the hemispheres.'. ${ }^{24}$

Other writers invoked linguistic models and metaphors even more explicitly to account for cinematic universality. For Vachel Lindsay, cinema was a 'moving picture Esperanto' whose mode of visual decoding aligned it with Egyptian hieroglyphics and whose emergence was as impactful as the dawn of print culture. He proclaimed: 'Edison is the new Gutenberg. He has invented the new printing.'. ${ }^{25}$ Nearly a decade later, the Hungarian Béla Balázs would similarly propose that cinema's 'impact on human culture will not be less momentous' than that of the 'printing press.' ${ }^{26}$ But whereas for Lindsay moving pictures were still a form of picture-writing in their enmeshing of literal and symbolic meanings, for Balázs cinema held out 'the promise of redemption from the curse of Babel' and the conceptual instrumentalism of a word-inflected culture by making visible the 'true mother tongue of mankind', that is to say, the 'long-forgotten language of gestures and facial expressions'. ${ }^{27}$

These assertions of universality, however, were often fraught with contradictions. Thus, in a much-cited passage, Balázs reflects on the cinema as 'a machine that in its own way will create a living, concrete internationalism: the unique, shared psyche of the white man'. ${ }^{28}$ In some of these theories, as Mattias Frey argues, the presumed universal legibility of the image also sat uneasily with the idea that 'film was an expression of national characteristics'. ${ }^{29}$ In a way, these cinematic iterations of universalism reproduced what Rosi Braidotti defines as the Enlightenment's binary logic of identity and otherness as respectively the motor for and the cultural logic of universal Humanism', not infrequently as a way to bolster the national interests of nascent film industries on an emerging global market. ${ }^{30}$ This was especially evident in the US upon the arrival of the feature-length

24 Delluc, 'From Orestes to Rio Jim', 257.

25 Vachel Lindsay, The Art of the Moving Picture (New York and Toronto: Random House, 2000 [1915]), 177, 224.

26 Béla Balázs, Béla Balázs: Early Film Theory; Visible Man and The Spirit of Film, ed. Erica Carter, trans. Rodney Livingstone (New York and Oxford: Berghahn Books, 2010), 9.

27 Balázs, Béla Balázs, 14; 10.

28 Ibid., 14, emphasis in original. This passage would be modified in the late 1940s, when Balázs revised and combined his two books into one single work, Filmkultúra: A film müvészetfilozófiája (translated into English in $195^{2}$ as Film Culture: Theory of the Film). Instead of 'the standard white man' and its 'shared psyche', Balázs now speaks of 'an international human type' in 'the development towards an international universal humanity'. See Carter, Béla Balázs, 15 .

29 Frey, 'Cultural Problems of Classical Film Theory', 337.

30 Rosi Braidotti, The Posthuman (Cambridge: Polity Press, 2013), 15. 
film, which, as Hansen observes, was frequently advertised in terms of 'a seemingly unmediated appeal to sentiment and sympathy' that 'reduced all social, cultural, and historical differences to an essential humanity'. ${ }^{31}$ Although Hansen overstates that the 'celebration of film as a new universal language ultimately coincided in substance and ideology with the shift from primitive to classical modes of narration', given that universalisms existed since the advent of cinema, the idea certainly gained a new impetus with narrative cinema. ${ }^{32}$ This was so especially during and after the war, when, as Friedman notes, 'the film-as-universal language rhetoric flourishes, in part, because it acquires a new political resonance, getting grafted onto discussions about the prospects for a "World State". 33

Released in 1916, Intolerance was deeply implicated in these ideas, concepts and discourses. Although the film does not directly reference the Great War, it is peppered with historical battle scenes and ends with a suggestive extradiegetic sequence where the image of a battleground is superimposed over that of angels in the heavens high above. This emphasis on human conflict was a reminder of the futility of warfare, used to bolster the film's pacifist message at a time when war was raging around the world and President Woodrow Wilson's policy of neutrality was beginning to lose public support in the US. ${ }^{34}$ But Intolerance's universalism, as we shall see, cannot be reduced to its anti-war rhetoric, channelling cultural expressions as disparate as Walt Whitman's poetry, universal exhibitions and millennialist discourse, all mashed up into a grandiose narrative of human suffering in close-up.

Intolerance's narrative was as unusual as it was strategically designed to up the film's game and cement Griffith's name on the world cinema map. Although the film performed relatively well upon its release and impressed some critics, it estranged many others, going down in film history as a 'magnificent failure'. ${ }^{35}$ Crucial to Intolerance's monumentality was the temporal enlargement of its textual edifice, which, encompassing over 2000 years, was mirrored in its long running time (roughly 3 hours). $3^{6}$ As noted, the film's gestation started with the present-day narrative strand, or the Modern Story. Inspired by the news of a mine workers' strike in Colorado, this depicts the

33 Friedman, The Movies, 13.

34 On Intolerance's anti-war message, see Andrew Kelly, Cinema and the Great War (London and New York: Routledge, 2005), 13-23; see also Friedman, The Movies, 65-74.

35 Terry Reydan, cited in Hansen, Babel and Babylon, 130.

36 On the difficulty of ascertaining Intolerance's original length, see Russell Merritt, 'D. W. Griffith's Intolerance: Reconstructing an Unattainable Text', Film History 4:4 (1990): 337-375. 
plight of a working-class couple - the Dear One (Mae Marsh) and the Boy (Robert Harron) - as they face a series of fateful events: the couple's baby is taken away by reformists on the grounds that the Dear One is an unfit mother, while the Boy is wrongly accused of murdering a gangster. By contrast, the remaining strands, all added at a later stage, are reconstructions of historical events and religious myths: the fall of the Babylonian empire to the Persians in 539 BC; the Judeo-Christian story of the crucifixion of Jesus Christ; and the massacre of the Huguenots in France on St. Bartholomew's Night in 1572. What is more, Intolerance shuns away linearity by intermixing the four stories, turning 'from one of the four stories to another, as the common theme unfolds in each', as one of its first title cards announces.

The decision to situate the Modern Story within a transhistorical constellation was no doubt meant to solidify the film's universalist credentials through the depiction of a timeless humanity. In this respect, as William M. Drew has shown, a major influence was the poet Walt Whitman, from whom Griffith borrowed a 'total historical conception' by focusing 'on the continuity and unity of human experience through the centuries' ${ }^{37}$ Griffith even makes a direct reference to the 1855 edition of Leaves of Grass and the poem 'Out of the Cradle Endlessly Rocking', which appears in the film as the visual tableau The Woman Who Rocks the Cradle, famously played by Lillian Gish. Employed as a transitional device whenever the film jumps between historical periods and also referred to as the 'Uniter of Here and Hereafter' (another line in the poem), the tableau allegorises the 'cradle of humanity', as underlined in one publicity programme and confirmed by title cards: 'Today as yesterday, endlessly rocking, ever bringing the same human passions, the same joys and the same sorrows.' ${ }^{8}$

The publicity materials surrounding Intolerance similarly lauded its universal humanism. One programme commented on 'how the four stories alternate with one another until, in the climax of the last act, they seem to flow together in one common flood of humanity'.39 Another noted that the

37 William M. Drew, D.W. Griffith's Intolerance: Its Genesis and Its Vision (Jefferson, NC: McFarland, 1986), 89.

38 Publicity programme for 'Intolerance: Theatre Royal, Drury Lane', London (May 1917), held at the Bill Douglas Cinema Museum (BDCM), University of Exeter, Exeter. Item number: 18333 . One of the anecdotes surrounding Intolerance's cyclical conception of history is that it was down to Griffith's chancing upon a billboard stamped with the expression 'the same today as yesterday' on a trip to New York for the premiere of The Birth of a Nation. See Paul O'Dell (with the assistance of Anthony Slide), Griffith and the Rise of Hollywood (New York: Castle Books, 1970), 46. As O'Dell also notes, this expression appears as a sign in one shot at the beginning of the Modern Story, when millworkers are seen protesting.

39 'Intolerance: Theatre Royal, Drury Lane', BDCM. 
switching back and forth between the narratives added to the suspense 'as though some great tornado gave wings to the very soul of all humanity, past and present'. ${ }^{40}$ These ideas were then reiterated by Griffith himself. Thus, in the programme notes for the film's New York premiere, he explained that 'the purpose of the production is to trace a universal theme through various periods of the [human] race's history. Ancient, sacred, medieval, and modern times are considered'. ${ }^{41}$

On closer inspection, however, this all-encompassing human race reveals some fault lines and predilections. As Scott Simmon argues, the idea of a "race" that included Babylonians, Israelites, Frenchmen, and Americans requires a certain melting-pot ingenuity' and reinforced an 'Anglo-Israelite logic' according to which Anglo-Saxons descended from Jews 'whose ten tribes were themselves descended through the Persians and Babylonians'. ${ }^{2}$ More broadly, Intolerance eschews a confrontation with race through its disregard for historical accuracy. An example is the Judean narrative, where, as Griffith's assistant Karl Brown recalls, there was no concern with 'the actual physical appearance of Christ during his life as a man on earth' but, rather, with what people knew about that era from recreations found in 'Bible pictures, Bible calendars, Biblical magic-lantern shows, Christmas cards'. ${ }^{43}$

Cracks also appear in Intolerance's universality when one examines both the choice of the narrative strands and the uneven screen time they receive. As scholarship on the film has shown, the three historical narratives each emulated contemporaneous international film styles, with Intolerance textually reproducing the competition over which it attempted to assert its superiority. ${ }^{44}$ Moreover, while the historical segments differ in tone and style, special importance is accorded to the Babylonian narrative. This was not coincidental. For it is this narrative strand that allows Intolerance to invoke the myth of Babel, according to which Babylonians had built a tower to reach God who, outraged by such an ambition, scattered the people all over the world and made them speak different languages. Thus,

40 Film publicity press book: Intolerance, n/d, BDCM. Item number: 18262.

41 Cited in Scott Simmon, The Films of D.W. Griffith (Cambridge, New York and Melbourne: Cambridge University Press, 1993), 143.

42 Ibid., 143.

43 Karl Brown, Adventures with D.W. Griffith (London: Faber \& Faber, 1973), 135.

44 Whereas the French segment evoked the Films d'Art productions and the Judean Story the Passion Plays imported from France, the Babylonian narrative drew on Griffith's beloved Italian films. See Hansen, Babel \& Babylon, 173; Ismail Xavier, 'On Film and Cathedrals: Monumental Art, National Allegories and Cultural Warfare' in Lúcia Nagib, Chris Perriam and Rajinder Dudrah (eds.) Theorizing World Cinema (London: IB Tauris, 2012), 21-44; 28. 
a title card at the beginning of Act II indicates that the events portrayed are based on 'cylinders [that] describe the greatest treason of all history, by which a civilization of countless ages was destroyed, and a universal written language (the cuneiform) was made to become an unknown cypher on the face of the earth'. At the same time, the setting of Babylon - measuring 'over a mile in length and built to accommodate five thousand people' materialised Intolerance's quest to impress. ${ }^{45}$ Partly a response to Pastrone's aforementioned Cabiria, from which Griffith borrowed its elephant motifs (as dramatised in the Taviani brothers' Good Morning Babilonia, 1987), the setting was equally indebted to the realm of world's fairs. As the story goes, Griffith would have come across, while location scouting, the 'newly risen spires' of the Panama-Pacific International Exposition (1915), whose craftsmen were then hired to construct the film set. ${ }^{46}$

Intolerance's connection with universal expositions is significant. Griffith is said to have declared that 'it would be a crime to let the [Panama-Pacific] exposition come and go without perpetuating it in photography. I don't mean ordinary photography, but something stupendous [...] I mean, in short, a film drama that will mark another forward leap as great as that of The Birth of a Nation'. ${ }^{47}$ In turn, this invites a reading of the film's multistranded structure as the temporal translation of these fairs' hierarchical spatial organisation, which arranged stands, attractions and villages of human cultures according to colonial parameters and in such a way as to create the idea of a topographical journey through the world. The idea that Intolerance could take its viewers on a historical world tour was reiterated in its publicity. One programme noted how Griffith 'takes you from plain, home-like scenes of the present day to those in Judea in the time of the Nazarene. He carries you from Judea to the glories of mediaeval France. From France you go easily into the pomp and magnificence of ancient Babylon'. ${ }^{48}$

It is not a coincidence, in this context, that the film's promotional materials sometimes included global figures. To be sure, globes were not exclusive to Intolerance's publicity. A case in point is a UK programme (figure 5.1) for Griffith's previous The Birth of a Nation (distributed in many European countries after the war), which features a global image, with the US prominently visible, and the caption 'Griffith's Mighty Spectacle', thereby

46 Richard Schickel, D. W. Griffith: An American Life (New York: Limelight Editions, 1996), 309.

47 Cited in Robert W. Rydell, All the World's a Fair: Visions of Empire at American International Exhibitions, 1876-1916 (Chicago and London: University of Chicago Press, 1984), 231.

48 'Intolerance: Theatre Royal, Drury Lane', BDCM. 


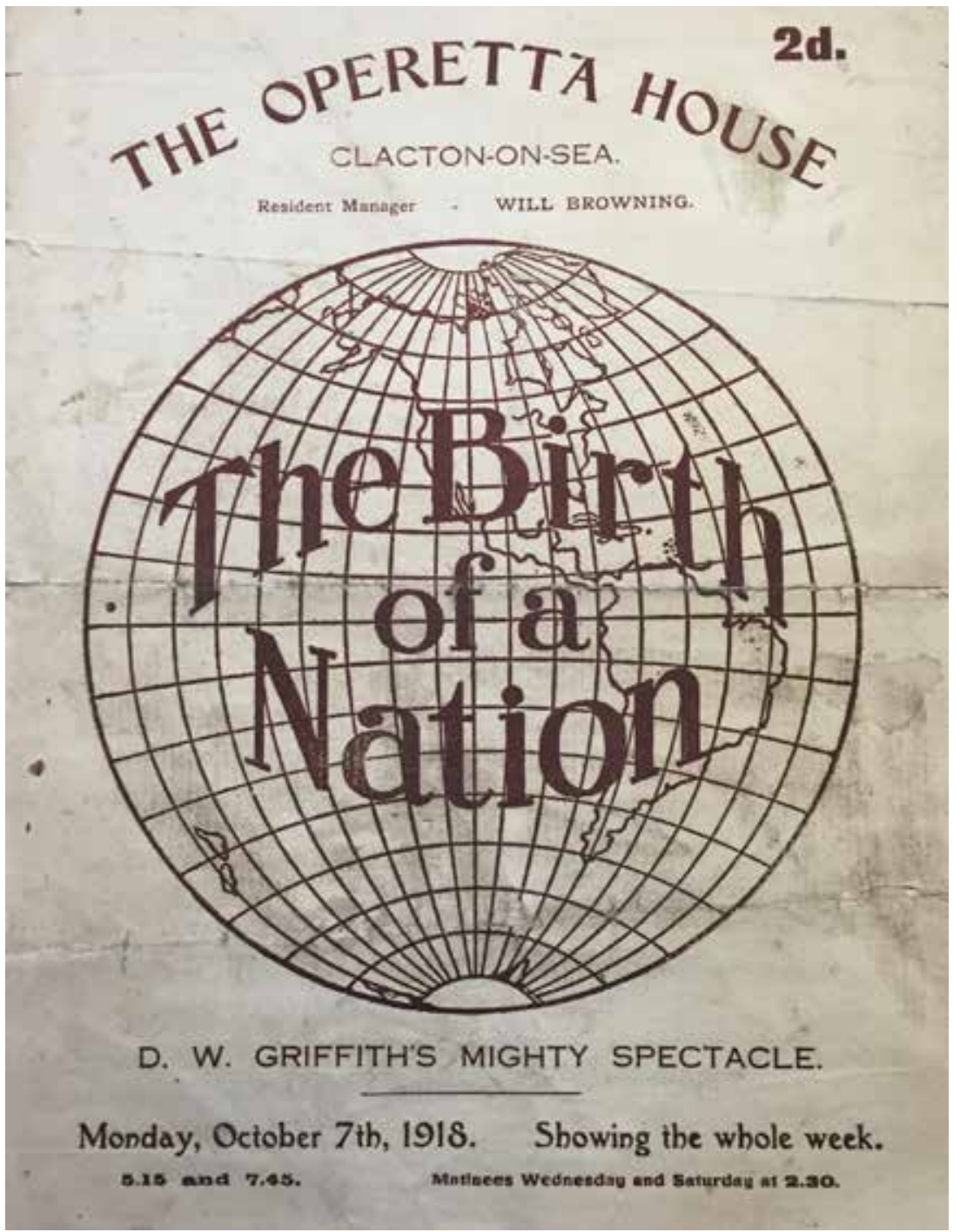

Figure 5.1 A programme for The Birth of a Nation (1915) reveals the global ambitions of its director. Courtesy of Bill Douglas Cinema Museum, University of Exeter.

confirming the global aspirations of this nation and this director. ${ }^{49}$ But in the case of Intolerance globes mirrored its totalising diegesis and betrayed its unequal apportioning of the world. One poster (figure 5.2), for example, lauded 'Griffith's colossal spectacle', in which 'the four paralleled stories

49 Publicity programme for 'The Birth of a Nation: Operetta House, Clacton-on-Sea' (October 1918), BDCM. Item number: 18710. 


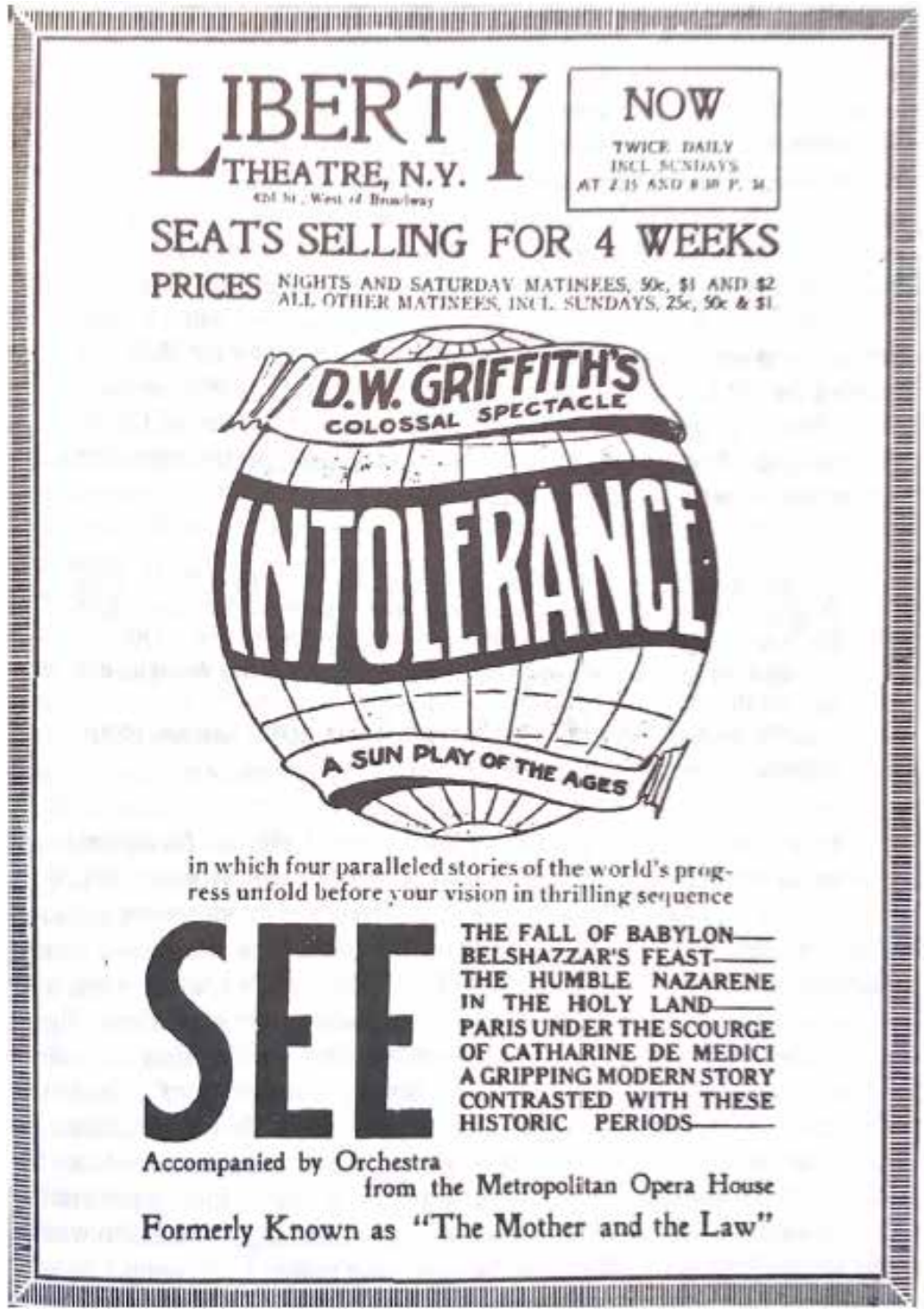

Figure 5.2 A poster for Intolerance (1916) reveals its world-encompassing aspirations and the unevenness of its world-making. Image reproduced in William M. Drew's D.W. Griffith's Intolerance: Its Genesis and Its Vision.

of the world's progress unfold in thrilling sequence', to then add that 'a gripping modern story is contrasted' with three different 'historic periods'..$^{0}$ These promotional lines spell out the film's uneven worlding, its gravitation 
towards the Modern Story. Not that this verbalisation was needed, though. In the film itself, the historical narratives, in spite of their differences, all come across as generalist and schematic when compared to the intricate design of the Modern Story, which instead displays Griffith's individualistic narrative inflection. Granted, some historical narratives are told through the lens of individuals: the unrequited love of the Mountain Girl (Constant Talmadge) for Prince Belshazzar (Alfred Paget) in the Babylonian narrative and the romance between Brown Eyes (Margery Wilson) and Prosper Latour (Eugene Pallette) in the French Story. Yet these individual stories are not fully developed, nor are these characters invested with the psychological nuances attributed to the Dear One or the Boy. The difference is even more glaring in relation to the Judeo-Christian narrative, which in the last instance remains a brief series of tableaus with no character or story development, confirming its placement by dint of its 'universal Christian appeal'.51

By emphasising 'the world's progress', these lines further reveal the film's conception of circular history to be a fallacy, traversed as it is by a teleological countercurrent, as Hansen has noted:

The temporal succession of settings - pagan antiquity, Judeo-Christian period, Renaissance-Protestantism, and the Modern Age - corresponds to a geographical movement from the Orient via the Mediterranean and Western Europe to the United States - and thus to the millennial prophecy that was mobilized in the nineteenth century by the ideology of Manifest Destiny: 'Westward the course of empire takes its way'. ${ }^{2}$

In turn, the film's tension between circularity and teleology is mapped onto montage alternation and acceleration. ${ }^{53}$ While Intolerance's first two hours devote lengthy sequences to each individual story, often separated by intertitles and The Woman Who Rocks the Cradle, towards the end noticeably faster intercutting climaxes in the film's most memorable and commentedupon sequence: a montage tour-de-force of crowd and battle scenes - the fall of Babylon, the crucifixion of Christ and the Huguenot massacre in Paris - all of which are intercut with the rescue of the Boy in the Modern Story.

$5^{1}$ Schickel, D. W. Griffith, 312. This being said, the Christian narrative was not conceived to be as short as it turned out. Griffith was allegedly forced to cut it down after film executives deemed its depiction of Jews unfavourable. See O'Dell, Griffith and the Rise of Hollywood, 46.

52 Hansen, Babel and Babylon, 170.

53 For an illuminating metric analysis of Intolerance's accelerating pace, see Yuri Tsivian, 'Beyond Comparing: The Internal Dynamics of Intolerance', Cinemetrics, http://cinemetrics.lv/ tsivian.php (last accessed 4 September 2020). 

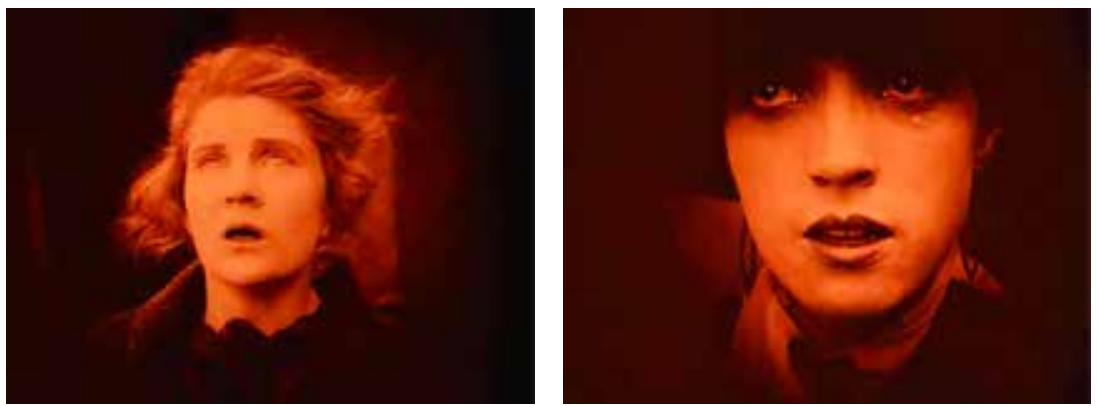

Figures $5.3 \& 5.4$ The universality of pain in close-up: the Dear One and the Friendless One in Intolerance.

As many commentators have noted, this montage sequence is revealing in that it culminates in the happy ending of the contemporary narrative, which announces the end of an eternally repeating history, itself materialised in the grief and gore closing the historical episodes. And indeed, despite the film's insistence that 'the same human passions, the same joys and the same sorrows' through the ages are depicted, there is little doubt that it is pain, in both its emotional and corporeal incarnations, that takes the upper hand in Intolerance as humanity's most universal attribute. As James Kendric summarises: 'Griffith gives us full view of two decapitations, bodies pierced by arrows, and an unedited shot of a character having a spear driven into his stomach, replete with gushing blood'. ${ }^{4}$ Emotional pain is, for its part, conveyed through facial close-ups of the female characters. Although Griffith's self-ascribing claim as the inventor of the technique no longer stands up to scrutiny, Intolerance does offer expressive uses of the close-up to convey sorrowful mental states: the Dear One's despair as she thinks about the Boy's hanging (figure 5.3); the Friendless One's remorse at having killed the Musketeer of the Slums (figure 5.4); the Mountain's Girl's resignation when confronted with her own death; and Brown's Eyes' horror at the prospect of being killed. 55

Intolerance's humanity is, then, a suffering humanity: a universal network of sorrows. On a narratorial level, this is articulated via the film's reliance on chance and fatalism both when considering its overall structure, which

54 James Kendrick, Hollywood Bloodshed: Violence in 1980 s American Cinema (Carbondale: Southern Illinois University Press, 2009), 26.

55 On Griffith as the self-proclaimed inventor of the close-up and its connection with universalism, see Mary Ann Doane, 'Facing a Universal Language', New German Critique 41:2 (2014): 111-124; $111-115$. 
reiterates a ceaselessly self-repeating history, and in relation to the Modern Story, in which the Dear One and the Boy are repeatedly characterised as having no agency or control over their lives. Didactic intertitles drive the point home: the 'Loom of Fate weaves death for the Boy's Father'; 'Fate leads them all to the same district'; 'the Boy [is] wrongly convicted by some mischance of fate'. On the other hand, the Boy does get saved in the end, heralding the end of history's preordained cycles of human misery. What causes history to stop repeating itself after all?

One may argue it is simply chance as materialised in a plot contrivance: the unexplained appearance of the Kindly Officer who helps the Dear One to find the real culprit. Incidentally, this is in tune with Griffith's 'social-problem' films, such as A Corner in Wheat (1909), The Usurer (1910) and What Shall we Do with Our Old? (1911), in which, as Moya Luckett notes, 'resolutions emerge through chance, result from individual actions, or are simply unavailable'. ${ }^{6}$ Also in line with Griffith's dramaturgy is the fact that the poor in Intolerance never become aware of the wider social structures dictating the course of their lives, nor is collective action presented as a possible means of bringing about change.$^{57}$ As Eisenstein once remarked:

In social attitudes Griffith was always a liberal, never departing far from the slightly sentimental humanism of the good old gentleman [...] His tender-hearted film morals go no higher than a level of Christian accusation of human injustice and nowhere in his films is there a sounded protest against social injustice..$^{8}$

This statement especially resonates with Intolerance, since the Boy is correlated with Jesus Christ at the film's end through crosscutting, which alternates his walk to the gallows with the crucifixion of Jesus in Golgotha. From this perspective, the prevention of the Boy's death appears not so much a product of chance but a miracle that announces the millennialist rebirth of Christian values. ${ }^{59}$ This reading, in turn, finds substantiation in the film's closing sequence, where a battleground is superimposed over

56 Moya Luckett, 'Space, Gender, Oversight, and Social Change: Progressivism and the Films of D.W. Griffith, 1909-1916' in Charlie Keil (ed.) A Companion to D.W. Griffith (Oxford: Wiley Blackwell, 2018), 309-329; 311.

57 See Doyle Greene, The American Worker on Film: A Critical History, 19o9-1999 (Jefferson, NC, and London: McFarland \& Company, 2010), 21, 29.

58 Sergei Eisenstein, Film Form: Essays in Film Theory, ed. and trans. Jay Leyda (San Diego, New York and London: Harcourt, 2011), 233.

59 Drew, D.W. Griffith's Intolerance, 20. 
angels in the heavens, prisons turn into flowery fields and a luminous cross shines through, above in the sky.

Yet, as has been noted, the Modern Story also strongly implies that technology can change the course of things or, to use the film's own lexicon, that it can alter the twists of fate, especially when we turn to the film's climatic montage sequence. For Hansen, 'the teleology of history manifests itself in the progress of technology, the superior means of transportation and communication that make possible the last-minute rescue of the Modern story', since the Dear One stops the Boy's execution through recourse to cars, telephones and trains. ${ }^{60}$ Following in Hansen's footsteps, Francesco Casetti has examined the sequence's 'breakneck speed' and Friedman the narrative and symbolic function of the automobile in the Modern Story as the bearer of such velocity. ${ }^{61}$

Inspired by these readings, I also want to close my analysis by drawing attention to the technological advancements figured in the Modern Story's ending. I want, however, to emphasise a different aspect, namely the fact that such advancements constitute, quite literally, a network linking geographically distant sites. This is highlighted through a number of shots showing railways and motorways (figures 5.5 and 5.6), as the Dear One chases by car the train carrying the Governor who can stop the execution, followed by images of officers calling the prison on a telephone, which delays the hanging. Intolerance's focus on railroads perpetuates a fascination with the subject seen in preceding popular visual media in the US. As Brooke Belisle has shown, 'expanding networks of railroad lines offered a particularly good subject for nineteenth century photographic sets' not only because they helped visualise progress through a series of photographs implying a connecting line across vast expanses, but also because 'materially uniting the country became a pressing national challenge [...] weighted with ideas of Manifest Destiny'. ${ }^{62}$

Intolerance subscribes to these imperatives. But it also updates the network via film-specific devices designed to expand its reach beyond the nation and across time. While, as Belisle notes, photographic sets of railroads encompassed 'an extended scale of space and time' that defied human perception through omitted chunks and gaps, these sets were still

60 Hansen, Babel and Babylon, 170.

61 Francesco Casetti, Eye of the Century: Film, Experience, Modernity, trans. Erin Larkin with Jennifer Pranolo (New York: Columbia University Press, 2008), 117-123; Friedman, The Movies, 83-90. 62 Brooke Belisle, 'Picturing Networks: Railroads and Photographs', Amodern 2 (2013), https:// amodern.net/article/picturing-nineteenth-century-networks/ (accessed 2 September 2020). 

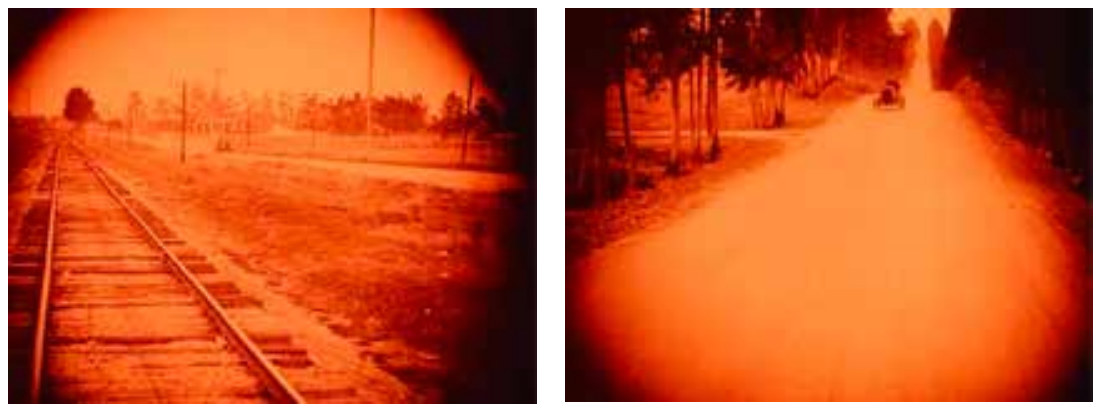

Figures 5.5 \& 5.6 Railways and motorways in Intolerance constitute a physical network.

modelled on spatiotemporal unidirectionality. ${ }^{63}$ Though this is also the case when it comes to the Modern Story, things become more complicated when we turn to the intermingling of geographical settings and time periods jumbled up in Intolerance's final section via montage. Christian Metz, for example, speaks of a mixture that 'becomes a visual whirlpool' and gains 'the affective status of a fusion'. ${ }^{64}$ Along similar lines, Friedman notes that 'the four stories ultimately intersect, resolving themselves into an image of unity that is decisive with respect to human history'. ${ }^{6}$ For Friedman, this is corroborated by Griffith's own assertion, reproduced in a programme mentioned above, that 'in the climax of the last act, [the four stories] seem to flow together in one common flood of humanity' ${ }^{66}$

Although the biblical imagery of this metaphor is far removed from urbanised networks, it produces a mental picture of divergent lines coalescing into one single point, not unlike a map or current digital modes of network visualising. At the same time, the four stories' fusion and intersection, emphasised via editing through graphic and compositional similarities (often between motorised and animal-based means of transport), gain in significance when examined next to Griffith's cherished crosscutting technique, which Intolerance radicalises in both form and content. Indeed, if parallel editing in Griffith's films was often employed to 'see more of the world' and 'bring together different worlds', as Luckett has suggested, then Intolerance takes this idea to new heights in its quest

63 Ibid.

64 Christian Metz, Language and Cinema (The Hague: De Gruyter, 1974), 107-109, emphasis in original.

65 Friedman, The Movies, 79, emphasis in original.

66 Ibid. 
to bring together different worlds into a figuration, or networking, of the whole world. ${ }^{67}$

No doubt this commingling of 'different worlds' is miles away from the more recent concept of 'small worlds' according to which developments in one corner of the planet can have a demonstrably physical impact in another in the manner of a 'butterfly effect' traversing the vagaries of space and time. ${ }^{68}$ From a metaphysical perspective, however, the small world of the Modern Story does have a retroactive impact on the worlds that temporally antedate it within the diegesis - not so much by changing the fate of those historical worlds in time-travel fashion, but by transfiguring the circularity of world history into the teleological linearity of progress.

That this linearity finds material configuration in highway, railroad and telecommunication networks is therefore significant insofar as it is this configuration that provides a physical grounding to the film's metaphysical networks. To use Griffith's own religious metaphor of floods and flows, the merging of the four stories into one single flow whose commanding steer is the contemporary narrative means that Intolerance's transhistorical intersecting is effectively mapped onto the actual, intersecting lines of roads and cables leading to the saving of the Boy. And insofar as the Boy is directly associated with Christ, we may be forgiven for concluding that his saving signals, in the film, the dawn of a universal history which, as it turns out, is also that of a global network society.

\section{A World of Strangers}

If Intolerance's spatial networks are restricted to one geographical locale and serve as the foundation onto which its temporally entangled, world-historical networks are grafted, in the contemporary global network narrative human flows are spatialised across the globe thanks to actual means of locomotion. Emerging on the world cinema map in the early 1990s, the network narrative has proved to be a genre uniquely suited to depict globalising processes related to the digital revolution, migratory displacements and tourism mobility. As Amanda Ciafone notes, via Jameson, the multinarrative can be understood as 'the filmic representation of the political unconscious of globalization' in its attempt to narrativise a world system whose vectors

67 Luckett, 'Space, Gender, Oversight', 318-319.

68 See Duncan J. Watts, Small Worlds: The Dynamics of Networks between Order and Randomness (Princeton, NJ, and Oxford: Princeton University Press, 2004). 
and forces impinge upon the personal and the local. ${ }^{69}$ Global multiplot films equally make visible what Arjun Appadurai calls our 'ethnoscape': 'the landscape of persons who constitute the shifting world in which we live: tourists, immigrants, refugees, exiles, guest workers, and other moving groups and individuals' ${ }^{70}$ Fernando Meirelles's 360 (2011), for example, follows the trajectory of more than half-a-dozen characters in Vienna, Paris, London and Colorado, with many scenes taking place in the 'non-places' of global modernity - airports, airplanes and hotel rooms - and recurrent shots of airplanes acting as a visual motif joining otherwise unrelated stories and characters. ${ }^{71}$

On an industrial level, the global network narrative also mirrors and is made possible by what Ciafone terms a 'networked industrial production (complex, temporary, and often transnational in financing, production, and distribution)' characteristic of our neoliberal age. ${ }^{72} 360$ is again a case in point. Directed by a Brazilian filmmaker, it brought together production companies from the UK, the US, Austria, Brazil and France, while featuring a vastly international cast from Czechoslovakia, Brazil, Russia, the UK and the US. Alejandro González Iñárritu's Babel was similarly financed by five production companies from Mexico, the US and France, and featured American, Australian, Mexican, Japanese and Moroccan actors and nonprofessionals. In these cases, as Paul Kerr observes, via Raymond Williams, the global narrative thus appears as 'a kind of "structural homology" to the film's mode of production and the social relations of its production.' 73

In light of the above, we may conclude that the current network film is miles away from Intolerance's time-bending, quasi-mystical globalism. And yet when we consider the latter as a foundational effort to transmute the universal-language idea into a multinarrative structure that crystallises a network of human suffering, then it appears as a paradigmatic film to bear in mind. For indeed, whereas literature on the multinarrative film has abundantly examined questions related to narrative mechanisms and storytelling devices, one of the most striking yet still underexplored features

69 Amanda Ciafone, 'The Magical Neoliberalism of Network Films', International Journal of Communication 8 (2014): 2680-2704; 2682, http://ijoc.org/index.php/ijoc/article/view/2452/1213 (last accessed July 29 2018).

70 Arjun Appadurai, Modernity at Large: Cultural Dimensions of Globalization (Minneapolis: University of Minnesota Press, 1996), 33, emphasis in original.

71 Marc Augé, Non-Places: An Introduction to Supermodernity (London: Verso, 2008).

72 Ciafone, 'The Magical Neoliberalism', 2682.

73 Paul Kerr, 'Babel's Network Narrative: Packaging a Globalized Art Cinema', Transnational Cinemas, 1:1 (2014): 37-51; 38. 
of the genre is its quest to rekindle universalism through its situating of individual stories within a wider panorama. ${ }^{74}$ Although I do not have the space to provide a survey of the genre, whose films can of course feature variations in theme, tone and style, I now turn to Babel as the most exemplary incarnation of this drive.

To glance over Babel's mixed critical reception, littered with expressions such as 'incandescent self-importance', 'limitless ambition' and 'a grand wreck', is in fact to be immediately reminded of the canonisation of Intolerance as a 'magnificent failure'.75 Iñárritu's third feature, Babel was the culmination of a meteoric international career. It followed on from his impressive Mexican debut Amores Perros (2000) and the international co-production 21 Grams (2003). All scripted by Guillermo Arriaga, with whom the director publicly fell out after Babel over authorship issues, these three films ensured the two men would become household names, recognised for their multiplot narratives. But whereas Amores Perros was set in Mexico City and 21 Grams in Memphis, Babel raised the stakes of the genre to giddy global heights.

As its title suggests, and not unlike Intolerance, Babel is the work of a skilful director who believes in the idea of film as a universal language and who wants to leave his mark on world cinema. The fact that Iñárritu's stature has only grown in importance since Babel's release, with his last two films, Birdman (2014) and The Revenant (2015), earning him two consecutive Academy Awards for Best Director, suggests that he is heading in the right direction. These are different times and nearly a century separates Intolerance from Babel, with the latter film instead attuned to an 'ethics in a world of strangers', to cite the subtitle of Kwame Anthony Appiah's book..$^{7}$ Yet, as we shall see, it is striking that the religious myth of Babel makes an imposing resurgence, via a multinarrative architecture, in a film that similarly postulates universalism through bodies in pain and trapped by fate, thus confirming the obstinacy of cinematic tropes and figures of the universal across time.

Comprising four narrative strands, each set in a different country, Babel aims to paint a world beset by miscommunication, featuring six languages in

74 See footnote 11 in this chapter.

75 A.O. Scott, 'Emotion Needs No Translation', New York Times (27 October 2006), https:// www.nytimes.com/2006/10/27/movies/emotion-needs-no-translation.html (last accessed 25 October 2018); Peter Bradshaw, 'Babel', The Guardian (19 January 2007), https:/www.theguardian.com/film/2007/jan/19/drama.thriller (last accessed 5 September 2020).

76 Kwame Anthony Appiah, Cosmopolitanism: Ethics in a World of Strangers (New York and London: W.W. Norton \& Company, 2006). 
total: Spanish, English, Japanese, Arabic, Berber and Japanese sign language. In Morocco, Abdullah (Mustapha Rachidi) gives a rifle to his goatherd sons Yussef (Boubker Ait El Caid) and Ahmed (Said Tarchani) to protect the goats from jackals. Unconvinced that the rifle can 'hit as far as $3 \mathrm{~km}$ ' as they are informed by its previous owner, the brothers shoot at a tourist bus atop a mountain. The bullet hits the neck of Susan (Cate Blanchett), an American tourist who is on holiday with her husband Richard (Brad Pitt), following the death of their newborn son. As a result of this incident, the Mexican nanny Amelia, who tends to the couple's children Debbie (Elle Fanning) and Mike (Nathan Gamble) in San Diego, finds herself unable to attend her own son's wedding in Tijuana, south of the US border. Failing to find care for the kids, she decides to take them to the wedding with her nephew Santiago (Gael García Bernal), leading to disastrous consequences. On their way back to the US, Santiago breaks through the border after a confrontation with a border patrol guard, leaving Amelia and the two kids in the scorching Californian desert. Meanwhile, in Tokyo, Chieko (Rinko Kikuchi) is a deaf-mute girl struggling with isolation and the suicide of her mother, unable to connect emotionally and sexually with other men. Eventually we find out that her father Yasujiro (Koji Yakusho) was the owner of the rifle sold to the Moroccan family, leading the Japanese police to start following her.

Babel's human networks, then, appear not only in the form of tourism mobility but also in relation to the themes of immigration, borders and border crossing. In particular, Amelia's back-and-forth trip to Mexico makes visible what Castells defines as a contemporary 'global process of urbanization' characterised by 'the formation of a new spatial architecture made up of global networks connecting major metropolitan regions', which he, tellingly, illustrates with the very geographical region depicted in Babel. He writes:

Los Angeles is not the appropriate name for the actual spatial form of which it is only a component, because the relevant spatial unit comprises the entire Southern California Metropolis that extends from Santa Barbara to San Diego and Tijuana across the border [...] This is the undefined metropolitan region where 20 million people work, live, commute, and communicate $[. .$.$] , while retrenching in the polity of localities of a$ fragmented territory and identifying their diverse cultures in terms of ethnicity, age, and self-defined social networks. ${ }^{77}$ 
Babel entirely subscribes to this idea. Through its focus on immigration issues, it shows that the movements and flows enabled by this networked topography is not at all frictionless, but instead ridden with tensions and conflicts resulting from ethnic-cultural diversity and asymmetric relations of power.

On a global level, the connections between the four stories are only gradually revealed to the viewer, often via photographs as diegetic props. Thus, when waiting for the ambulance to arrive in the small village of Tazarine, Richard shows pictures of Debbie and Mike to the tour guide Anwar (Mohamed Akzham), whereas in Chieko's apartment the camera lingers for a moment on a picture on the wall showing Yasujiro holding the rifle. However, although the film alternates between the stories, which could lead one to infer they are simultaneous, this proves not to be the case. For example, Babel starts with Yussef and Ahmed shooting the rifle but then goes back in time to show Richard and Susan bickering in a restaurant. We are then made aware of this temporal disjuncture as the bullet incident is reprised, now from Susan's perspective on the bus. Similarly, at the film's beginning we hear Richard on the phone with his son the evening prior to the wedding only to realise, at the end, that the call has happened long after Susan's shooting. Another example is the Japanese narrative, which, though it is crisscrossed with the other stories through the film's running time, has taken place a few days after the Moroccan incident.

The gradual solving of this temporal puzzle reveals the two principles upholding Babel's network narrative: interconnection and parallelism. If at the start of the film the links between the stories are unclear, by its end all dots are more or less connected. By intercutting the four stories rather than having them unfold autonomously, an overt narratorial hand is foregrounded and the film's emotional impact heightened. As Laura Podalsky has argued: 'Babel reorders story events and juxtaposes sequences in particular ways as a means to reveal what it deems to be the true, affective connections between its characters. $7^{8}$ It must be noted, however, that $\mathrm{Babel}$ never blends all stories into one single whole via montage (as in Intolerance), and that the characters from different stories never brush against each other (a dominant trope of the multinarrative film). True, Gustavo Santaolalla's melancholy soundtrack does occasionally provide a bridge between transitions, some of which are based on graphic equivalences, as when poor kids running in Morocco turn into rich kids running in San Diego. Yet by and large transitions in the film

78 Laura Podalsky, The Politics of Affect and Emotion in Contemporary Latin American Cinema: Argentina, Brazil, Cuba, and Mexico (New York: Palgrave, 2011), 134. 
are often jarring and abrupt, which is in line with the discrepancy between the look of each narrative achieved via different film stock (a common feature of Iñárritu's multiplot films, all photographed by Rodrigo Prieto). ${ }^{79}$

Babel's imagining of the global thus oscillates between two poles. If on the one hand there is a quest for narrative unity, the fact that the stories retain a certain autonomy means that on the other the film resists homogeneity and in so doing could be described, to cite Mads Anders Baggesgaard, as an 'exploration of the intimate relationship between location and globality'. ${ }^{80}$ Indeed, location is emphasised through the film's style, which retains a documentary quality provided by handheld camerawork and fly-on-the-wall, street-life imagery, especially in the Japanese and Mexican narratives. But Babel is not merely interested in locality. The locatedness of one's place in the world is equally emphasised through its extensive use of point of view and hearing.

Thus, at points during Chieko's story, the film's aural track turns into barely audible vibrations so as to mimic her deaf-mute's perspective on the world. Likewise, point-of-view shots taken from inside vehicles convey what Deborah Shaw, in her analysis of the film, terms a 'tourist gaze' traversing foreign territories and confronting cultural difference. Examples include when Susan observes through the bus window burka-attired women walking in the Moroccan desert, or when Debbie and Mike stare with curiosity from the car at the bustling Mexican streets, and Mike tells Santiago that 'Mexico is a dangerous place'. ${ }^{81}$ Yet the film also inverts the direction of looks and qualifies the safe distance of the tourist gaze as fragile. This is what happens, for example, when Michael and Debbie are stared at on their arrival at the party in Mexico, as well as when the American and English tourists become themselves an attraction for the people of Tazarine as the bus is forced to stop there. The seeing-through-glass motif reappears here, but now with the tourists depicted from inside the bus through the bullet-broken glass.

By foregrounding the phenomenology of one's being in the world via subjective hearing and looking, Babel calls to mind Hannah Arendt's concept of 'common world', which she defines thus:

79 Dolores Tierney, 'Alejandro González Iñárritu: Director without Borders', New Cinemas: Journal of Contemporary Film 7:2 (2009): 101-117; 105.

80 Mads Anders Baggesgaard, 'Picturing the World - Cinematic Globalization in the Deserts of Babel', Journal of Aesthetics \& Culture 5:1 (2013): 1-10; 2.

81 Deborah Shaw, The Three Amigos: The Transnational Filmmaking of Guillermo del Toro, Alejandro González Iñárritu, and Alfonso Cuáron (Manchester: Manchester University Press, 2013), 141. 
For though the common world is the common meeting ground of all, those who are present have different locations in it, and the location of one can no more coincide with the location of another than the location of two objects. Being seen and being heard by others derive their significance from the fact that everybody sees and hears from a different position. ${ }^{82}$

Babel's replication of the same event from different perspectives - such as Susan's shooting and Richard's telephone call to Amelia - is another stance of this non-synoptic and multi-perspectival world-making. As Arendt notes: 'The end of the common world has come when it is seen only under one aspect and is permitted to present itself in only one perspective'. ${ }^{83}$

Clear-cut dichotomies - us and them, north and south, east and west - are further blurred in Babel by the fact that misunderstanding is also depicted between people from the same culture and/or speaking the same language, meaning the film's title is to a certain extent a red herring. No doubt linguistic miscommunication is a recurrent trope, as when Richard cannot be understood by a Moroccan driver when crying out for help; or when, on driving back to the US after the wedding, an intoxicated Santiago tells a confrontational US-Mexico border guard that Amelia is the kids' 'auntie', only for this to be disproved by Debbie. However, conflicts also arise between people speaking the same tongue. Episodes that substantiate this include Richard and Susan's bickering on the bus, the escalating row between Richard and the American and English tourists (who become impatient due to the ambulance's delay), Chieko's series of failed sexual and emotional encounters with other Japanese men, as well as her frustrating relationship with her father.

At least in principle, this effort at levelling humanity out beyond cultural and linguistic particularisms calls to mind Alain Badiou's indictment of a contemporary 'ethics of difference' (as also discussed in chapter 4). This Badiou defines as a 'commonsensical discourse defeated in advance', given that 'infinite alterity is quite simply what there is': 'There are many differences, say, between a Chinese peasant and a young Norwegian professional as between myself and anybody at all. ${ }^{84}$ It follows for Badiou that 'the real question - and it is an extraordinarily difficult one - is much more that of

82 Hannah Arendt, The Human Condition (Chicago and London: Chicago University Press, 1958), 57 .

83 Ibid., $5^{8}$.

84 Alain Badiou, Ethics: An Essay on the Understanding of Evil, trans. Peter Hallward (London and New York: Verso, 2012), 25-26, emphasis in original. 
recognizing the Same, ${ }^{85}$ Universality in this account has little to do with a transhistorical human nature or an a priori Kantian morality, but what Badiou terms 'a truth', the possibility 'to think what might be in terms that break radically with what is', which is 'the obligatory starting point of all properly human action' ${ }^{86} \mathrm{He}$ concludes: the 'coming-to-be of that which is not yet' that constitutes a truth and arises in particular, contingent events must be by necessity universalisable, that is, 'indifferent to differences', since 'a truth is the same for all'. ${ }^{87}$

On the basis of its adherence to multiplicity, the multinarrative film would seem to appear as a privileged dramaturgic space around which notions of universality and alterity can be negotiated and contested, often to diverse ends. The Oscar-winning Crash (Paul Haggis, 2001) is a good example: featuring characters pertaining to ethnic minorities living in Los Angeles, such as Afro-American, Latino and Arabic communities, here is a film interested in bolstering a schematic discourse of difference through characters whose identities are defined by their ethnicity a priori, and who will de rigueur display racist attitudes towards other ethnic groups. Conversely, Badiou himself has examined Paul Thomas Anderson's fascinating Magnolia (1999), which interlocks the lives of nine characters during a rainy day in Los Angeles, as 'allegorical of humanity as a whole', with the film informed by 'a tension between the desire for multiplicity and a counter-tendency toward unity'. ${ }^{88}$ For Badiou, Magnolia's affirmative universalism is: 'humanity is love. When there's no love, then there's no humanity, there's only disconnection, in the strict sense of the term. ${ }^{89}$

To return to Babel, although the film grapples with these ideas, its thesis nonetheless proves to be removed from a Badiounian affirmation of human love and agency. The film instead locates its universality in the spectatorial recognition of pain and suffering. Iñárritu himself explains: 'I realized that what makes us happy as human beings could differ greatly but what makes us miserable and vulnerable beyond our culture, race, language or financial standing is the same for all'. $9^{\circ}$ Such a statement, in turn, recalls the work of pragmatist philosopher Richard Rorty, for whom only witnessing the pain of others can activate a bond between fellow humans. For Rorty,

85 Ibid., 25, emphasis in original.

86 Ibid., 14.

87 Ibid., 27, emphasis in original.

88 Alain Badiou, Cinema, texts selected and introduced by Antoine de Baecque; trans. Susan Spitzer (Cambridge and Malden, MA: Polity Press, 2013), 178, 176.

89 Ibid., 183, emphasis in original.

90 Iñárritu cited in Shaw, The Three Amigos, 148, my emphasis. 

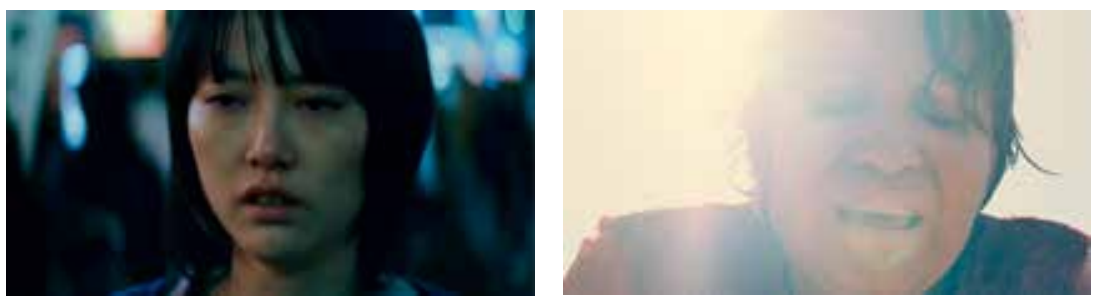

Figures 5.7 \& 5.8 The universality of pain in close-up: grieving women in Babel. Courtesy of Paramount Vintage.

human solidarity should not be thought of 'as recognition of a core self, the human essence, in all human beings' but, rather, 'as the ability to see more and more traditional differences (of tribe, religion, race, customs, and the like) as unimportant when compared with similarities with respect to pain and humiliation'..$^{11}$

Pain and humiliation are indeed the lingua franca of Babel, which revels in its own ability to convey these mental and physical states as viscerally as possible. Claustrophobic framings, out-of-focus shots, frenetic editing and erratic camerawork are all recruited to depict graphic events literally drenched in bodily fluids. And as in Intolerance, it is mostly women who predictably bear the brunt of suffering as universalising signifiers of martyrdom. We follow Susan's ordeal as she bleeds uninterruptedly, eventually pees herself and then has her gun-inflicted wound stitched by a veterinarian with no anaesthetic, all in extreme close-ups. We witness the comedown of Chieko's drug-fuelled night out as she walks, inconsolably, back home, her face all gloom and sweat (figure 5.7). And we are asked to participate in Amelia's plight in the scorching desert wearing a tight dress and high-heel sandals, her sunburnt face smeared with makeup (figure 5.8) and her feet bleeding in close-up. Tearful faces, twitching hands, fatigued legs: in Babel, the human body is truncated into synecdochal signifiers of pain and nothing escapes the attention of a camera eager to make the viewer feel intimately close with physical affliction as the conduit for universality.

In conformity with the network film, Babel's rollercoaster of dehumanising situations is triggered by a chance event - an accidental bullet - that triggers other, increasingly harrowing events in an uncontrollable domino, or butterfly, effect. As Bordwell tells us, 'contingency replaces causality' as the motor of the network narrative, a staple of the genre that has been 
positively appraised: either because, as Charles Ramírez Berg argues, contingency shows that 'agency is illusory and self-actualization risible'; or because, as noted by Todd McGowan in relation to Babel, as 'a film that bombards the spectator with the power of contingency', it proves 'that no underlying guarantee provides support for the sociosymbolic structure', hence the possibility of change..$^{2}$ On closer inspection, however, chance and contingency are not so much figured in the network narrative as the emergence of a Badiounian truth that can be seized as a catalyst for change, as they are channelled into determinism and fatalism. To use Jeffrey Sconce's blunt but useful expression: characters in the network film are often 'fucked by fate', and nowhere is this more evident than in Babel..$^{93}$

It is true that in the end some characters in Babel are fucked by the wrath of fate more royally than others, whether because of their geographical provenance, social class or ethnicity. As in Intolerance, salvation may come for some, but certainly not for all. Although we can discern glimmers of connection and redemption in the stories of Richard and Susan and of Chieko and Yasujiro, this is hardly the case when it comes to Amelia or the Moroccan children. Indeed, I cannot follow McGowan's contention that the contingency of the shooting ultimately connects, in his words, 'Yussef and his family in Morocco, Richard and Susan visiting the country, Amelia and her family in Mexico, and Chieko and her father in Tokyo' ${ }^{94}$ While Amelia is informed that Susan and Richard have decided not to press charges against her, she is immediately deported back to Mexico, literally in rags, because she had been working illegally in the US. Tellingly, when she is informed of this decision, a close-up emphasises her fidgeting hands, which sits in contrast with the visual motif of holding hands (seen in the stories of Richard and Susan, and Chieko and her father) that McGowan treats as proof of the film's affirmative ethics. Yussef's future prospect could not be less promising either: the last time we see him he is sobbing in despair as his brother is killed by the police during a shootout.

92 Bordwell, Poetics of Cinema, 204; Charles Ramírez Berg, 'A Taxonomy of Alternative Plots in Recent Films: Classifying the "Tarantino Effect"', Film Criticism 31:1/2 (2006): 5-61; 40; Todd McGowan, 'The Contingency of Connection: The Path to Politicization in Babel', Discourse 30:3 (2008): 401-418; 403 .

93 Jeffrey Sconce, 'Irony, Nihilism and the New American “Smart” Film', Screen 43:4 (2002): 349-369; 363 .

94 McGowan, 'The Contingency of Connection', 413. McGowan's analysis substantiates this claim with examples only from Susan's and Chieko's stories $(413,415)$. See also Bert Olivier, 'Communication and "Real" Confusion: The Film Babel', Communicatio: South African Journal of Communication Theory and Research, 35:1 (2008): 1-16. 
Granted, it could be argued that the film highlights the brutal fate that awaits these disenfranchised characters by subscribing to the rules of verisimilitude, that is, 'from a position of sympathy and identification with the residents of the Global South', as Dolores Tierney argues. ${ }^{95}$ In this context, the televised departure of Susan from the Moroccan hospital watched by the Japanese detective just before the film ends, with the TV presenter highlighting the 'happy ending for the American couple', would confirm Babel's knowing recognition of an unjust world system that benefits some to the detriment of many. The problem, in my view, is that the film risks perpetuating the very partition it aims to obliterate by characterising those residents of the global south solely as the recipients of pity. It thus reinforces what Badiou defines as a 'miserable moralism in the name of which we are obliged to accept the prevailing way of the world and its absolute injustice..$^{6}$ Arendt similarly warns us about the dangers of a politics of pity, which, by requiring an unbridgeable distance between those who suffer and those who watch, 'can be enjoyed for its own sake, and this will almost automatically lead to a glorification of its cause, which is the suffering of others'. ${ }^{97}$ This leads us back to the film's fatalism and the little agency it accords its characters, a feature of the network narrative that Berg defines as 'seriously subversive' in its deconstruction of the myth of American individualism..$^{8}$ And yet a world entirely devoid of human agency and purely governed by fate is just another name for nihilism, which, as Badiou notes, 'is a powerful contributor to subjective resignation and acceptance of the status quo'.99

Like Intolerance, Babel lauds cinema as a substitute for verbal language in connection with pain and suffering seen up close. In place here, to cite Rorty, is a belief that, within humanity, 'a nonlinguistic ability, the ability to feel pain, is what is important, and that differences in vocabulary are much less important'. ${ }^{100}$ But Intolerance and Babel are also such revealing texts across the temporal gulf that separates them because they evince the limitations of a sentimental humanism. To construct a grief-stricken

95 Dolores Tierney, New Transnationalisms in Contemporary Latin American Cinema (Edinburgh: Edinburgh University Press, 2018), 91.

96 Badiou, Ethics, lv.

97 Hannah Arendt, On Revolution (New York: Penguin Books, 2006), 218. Karl Schoonover has explored Arendt's politics of pity in relation to the brutalised body of Italian neorealism. See Brutal Vision: The Neorealist Body in Postwar Italian Cinema (Minneapolis: University of Minnesota Press, 2012), xiv.

98 Berg, 'A Taxonomy of Alternative Plots', 40-41.

99 Badiou, Ethics, 32.

100 Rorty, Contingency, 88. 
networked humanity, both films must rely on an unforgiving fate that can only produce marionettes for a history that has already been written or a reality that cannot be changed. Whereas Intolerance's salvation comes through a miraculous conflation of theology and technology, Babel shows instead nihilistic resignation in the face of the ways of the world by succumbing to an aesthetic mythologising of the suffering body.

\section{Networking the Earth}

On first inspection, Eduardo Williams's debut feature The Human Surge (El auge del humano, 2016) could not be further removed from Intolerance and Babel. A hybrid between fiction and documentary directed by a young Argentinean, this small-budget film does not attempt to construct the ambitious Babelistic edifice on display in those films. Still, I want to argue in the remainder of this chapter that The Human Surge does reveal important ties with the network film. This is seen not only on a structural level, in the sense that the film interweaves three disparate stories across the globe, but also on a thematic one, with human connectivity an overarching topic. More importantly, The Human Surge is a useful text to examine against Intolerance and Babel because it offers a refreshing antidote to sentimental universalism. This is achieved both by its refusal to abide by the precepts of a suffering-based human community and the way it expands the network into more-than-human realms, which results in a grounded, earthly, indeed earthy perspective on the Earth.

Winner of the main prize in Locarno's Filmmakers of the Present competition in 2016, and a co-production between Argentina, Brazil, and Portugal, The Human Surge is divided into three parts, each of which episodically unfolds from start to finish. The film starts with the young Exe (Sergio Morosini) in Buenos Aires, Argentina, jumps to Maputo, Mozambique to follow Alf (Shine Marx), and ends on the Philippine island province of Bohol, with a few unnamed young characters. As in Babel and other multiplot films, these strands are formally differentiated by film stock: the first was filmed on $16 \mathrm{~mm}$, the second on a pocket camera whose images were then recorded from a monitor by a $16 \mathrm{~mm}$ camera, and the third on a digital RED camera. ${ }^{101}$ As far as its network narrative goes, however, one 
of the film's original features resides in how it interrelates its characters, for the connections that bring them together, as discussed below, are not causal in terms of a 'butterfly effect'. Featuring non-professionals in all roles, and more than a dose of improvisation, the film moreover eschews depth of characterisation and story development: comprising long tracking shots trailing characters from behind, The Human Surge is more profitably understood as a collection of fragments of everyday life, including a focus on boredom and restlessness, but also on uncomplicated pleasures against the backdrop of natural settings.

One of the main features of the global network society, according to Castells, is a 'shift from traditional mass media to a system of horizontal communication networks organized around the Internet and wireless communication', which has ushered in 'a fundamental cultural transformation, as virtuality becomes an essential dimension of our reality'. ${ }^{102}$ In The Human Surge this idea becomes one of the main axes around which the parallelisms and links between characters are established. Connecting all young men and women in the film, in the three different locations where the film is set, is their dependence on electronic gadgets resulting from an inability to cope with everyday reality and as a way to escape to the virtual world of text messages and online videos. Many scenes accordingly show characters holding their devices, in search of a wireless connection, walking and texting, or simply lying around glued to their phones. At one point in the Mozambican strand, Alf tells his friend Archie that 'it's the second time my telephone has been stolen', and later says he 'can't be without my phone'. Phrases such as 'I've just checked on the Internet' and 'I've seen it somewhere on the Internet' are similarly heard in chaotic group conversations.

That said, The Human Surge is no celebratory take on millennials, globalisation and technology, given its critical focus on issues of class. All characters in the film are uniformly disenfranchised and from the so-called global south, often living in modest if not shabby houses, and mostly unhappy in second-class jobs, when not jobless. While at the film's start we see the Argentinean Exe working in a warehouse supermarket, later the viewer learns that he has been fired 'yet again'. In another scene, in the Mozambican story, Alf confides, to his friends' amusement, that he is thinking of leaving his job. Cryptic, disconnected phrases like 'They need us to be in debt, really' and 'What are the millionaires going to do? We have to wake up early. I hope their fortunes never decline!', often dropped unexplainably, further underscore the social class to which these youngsters belong in the context 
of an asymmetrical world system that feeds off inequalities. This point is pressed home in the film's closing sequence, filmed in Bohol. It shows a factory assembly line and workers putting together a tablet whose integrated circuit, with its tiny and interconnected resistors shown in close-ups, lends material form to the film's emphasis on wireless networks.

Unlike these sleek tablets, the devices used by characters in The Human Surge are old, broken or malfunctioning. Internet connection is similarly never a given for these young people. They are constantly in search of a free connection or, as in the case of the young Filipino woman in the last narrative strand, in urgent need of an Internet café for reasons that remain undisclosed. In short, the myth of a democratising and inclusive Internet as the new universal language of our time finds no place here. As Friedman notes:

It remains commonplace to infer from the decentralized structure and easy accessibility that [social media networks] are threats to repressive regimes, tools of democratic self-expression that empower common people by enabling them to connect and interact. The speed with which certain words and images can spread across the network seems to realize the ideal of a universal plane of cultural experience. ${ }^{103}$

By showing such 'easy accessibility' to be not so easy after all, The Human Surge is sceptical of this new universalism. As Elena Gorfinkel rightly notes in her analysis of the film: 'For these youth, the virtues of the network form seem to be bound up in its promise, but in practical terms, it is in fact an architecture of failure, asynchrony, and unrequited desire'. ${ }^{104}$

If anything, The Human Surge is concerned with exposing the underbelly of the Internet via a focus on online pornography: an easy means of making cash for the destitute youth. This is depicted in the first episode, when Exe and a group of friends, not without nervous giggles, broadcast themselves live and semi-naked for a webcam, fiddling with their genitalia and performing fellatio on one another. While homoerotic, this scene also shows these sexual performances to result from the boredom that comes with being jobless and adrift. This is reiterated in the first transition between stories, which finds Exe on a computer displaying a video of young black boys playfully

103 Friedman, The Movies, 4.

104 Elena Gorfinkel, 'Introduction: Global Cinemas in a Time of Networks' in Elena Gorfinkel and Tami Williams (eds.) Global Cinema Networks (New Brunswick, NJ: Rutgers University Press, 2018), 1-20; 11 . 
staging anal and oral sex with a banana. The camera gradually closes in on the video, which then freezes due to a poor connection. When the image comes back to life, the viewer then realises that its visual source is no longer the computer monitor but the actual webcam filming in situ, which sets in motion the film's second strand in Mozambique. This transitional sequence thus functions as an interface that merges the digital and the real world into an image whose ontological status becomes momentarily indiscernible, thus resonating with a later shot showing Alf walking about town, which curiously displays a 'play' arrow symbol at the top-right of the frame.

However, if The Human Surge is populated by youngsters whose craving for virtual realities is unrelenting and palpable, the film's mise-en-scène and style act as a material antidote by focusing on embodied existence and the pulsing rhythms of the quotidian and the concrete. This is achieved via two interrelated formal strategies. The first is the durational quality of shots allied with a focus on mundane events. Whether we are following characters walking into densely tangled jungles, pottering about in a lagoon in the Philippines, wandering down the sinuous pathways of a hillside in Mozambique, or plodding through a flooded urban area in Argentina, The Human Surge foregrounds not only the instantaneous gratification of a connected world, but also the phenomenology of being-in-the-world, including its sensory and material pleasures. Miserabilism is here deterred through characters that, despite their precarious socio-economic status, are not defined as sorrowful victims. Against all odds, they enjoy themselves in the company of fellow humans and in natural settings, whether we think of Exe laughing away with his friends in a square in Buenos Aires or on the beach, or the extended sequence in the last narrative strand depicting a large group of people bathing in a swimming hole. Lasting eight minutes and filmed at water level, this merry sequence stays with these characters while they swim, chatter away, splash the water and joke around. While alluding to the asymmetry of the global network, The Human Surge nonetheless refuses to reduce its characters to bodily specimens of misery by underlining mundane pleasures in the natural world as both an affirmation of living in the physical world and as a counterpoint to the lure of the virtual world.

The second formal element worth noting is the ambulatory camerawork, which the film deploys when tracking characters from behind. Filmed without a Steadicam, these positively handheld shots reflect in the very constitution of the image the embodied contortions of the camera operator. This is especially the case when we consider the hilly, jagged and winding paths and alleys through which the camera traverses, with its erratic movements thus mimicking the phenomenological experience of traversing 

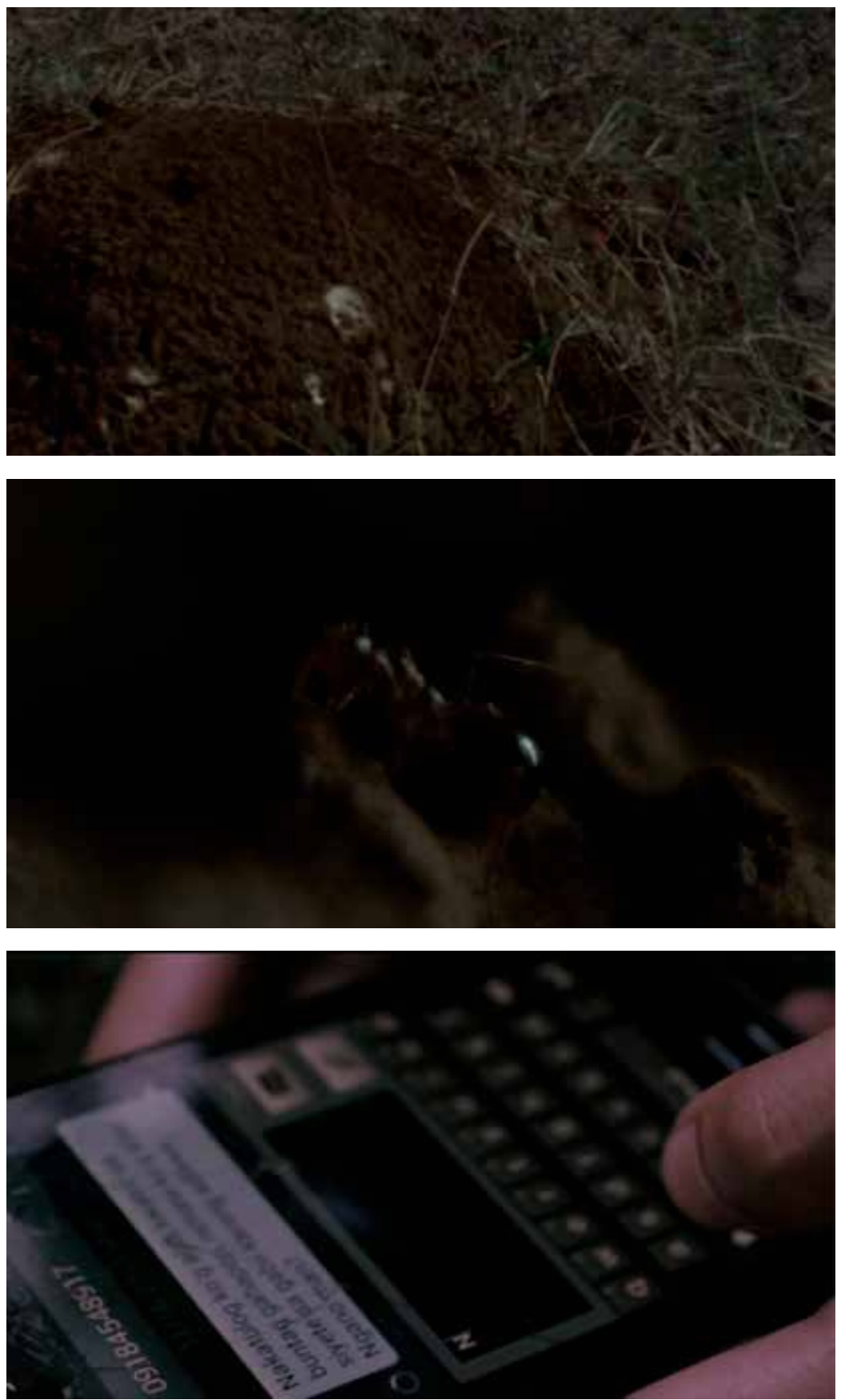

Figures 5.9, 5.10 \& 5.11 In The Human Surge (2016), an ant colony provides the entry to an underground journey via the center of the Earth, which acts as a counterpoint to the idea of technology as the primary connective tissue of our network society. Courtesy of RT Features. 
those settings. Although the resulting images are never coded as pointof-view shots, the camera seems to register an autonomous quality when decelerating, pausing or even changing its 'mind' as it stalks characters, not to mention the constant looks of passers-by, which underline further the corporeal I behind the camera's eye.

Yet if this view on the world seems to be coded as human, in the film's most memorable sequence this assumption no longer holds true. It shows Archie getting up at daybreak in an open field and urinating into an anthill, at which point the camera closes in on a hole on the nest (figure 5.9). This is followed by a wondrous, entirely unexpected interlude lasting over four minutes inside the nest. Instead of humans in full figure followed from behind - the film's main visual trope - the viewer is given the image of magnified ants occupying the entire screen (figure 5.10) to the sound of an atmospheric soundtrack. The ants then crawl out of the nest and on to a hand holding a smartphone, which brushes them off and begins typing in a message (figure 5.11), yet the geographical location is no longer Mozambique but the Philippines!

Rather than the digital interface connecting Argentina and Mozambique via wireless signals, the connection between Mozambique and the Philippines is instead forged through an underground journey across the center of the Earth, which acts as a counterpoint to the idea of technology as the primary tissue of our network society. That is, by halting a human-centric narrative to register an ant colony, the film relativises the world of characters not merely in relation to each other across the world (as is often the case in the global network narrative), but also in relation to the unseen world underneath our feet, and thus to a much wider, networked ecosystem that includes the natural environment and nonhuman animals.

Here, The Human Surge thus recalls not so much theories of network society but the 'actor-network-theory' (ANT), which, according to one of its most illustrious proponents, Bruno Latour, aims to trace the physical 'association between entities which are in no way recognizable as being social in the ordinary manner'. ${ }^{105}$ Curiously, as Latour notes, the acronym ANT is 'perfectly fit for a blind, myopic, workaholic, trail-sniffing' mode of enquiry: defining his project as 'an ant writing for other ants', this expression takes on added meaning in The Human Surge, where an ant colony reconfigures the global network society into an earthly - and earthy - one. In turn, this leads us to take the film's title with a pinch of salt and similarly 
to take issue with its English translation, which does not fully grasp the ironic nuances of the original. The Spanish title reads El auge del humano, with auge literally meaning 'peak' or 'height'. A more faithful if nonetheless cumbersome translation would thus read as 'The Peak of Humanity'. While such a peak is thematised in the film in relation to connective technology, its focus on the pathways and trails of an infinitesimal animal simultaneously relativises and satirises the human network.

If Intolerance postulates the technical networks of urbanity as the ground on which to proclaim the metaphysical redemption of humanity, The $\mathrm{Hu}$ man Surge replies to that film, exactly a century later, by showing that ultimately technology is only one among many other networks of which we humans are also, and more humbly, a part. Worthy of note here is that the film is replete with holes, hollows and subterranean motifs that imply the existence of mysterious links beyond the nets and webs of technology. At one point, for example, Exe mysteriously walks into a cellar, while, in another scene, he and a group of friends enter into a hole inside a giant tree. In the Mozambican narrative, Alf unexplainably peeps into a cone-shaped object, while in the last strand, a man mentions he 'fell into a dark hole'. When placed in relation to the hole into which the camera plunges to reveal the ant nest linking different continents across the Earth, these episodes cumulatively gain in significance as they intimate worlds whose opening up into the 'real' world remain unseen but no less real.

In their condemnation of an ethics of pity, both Badiou and Arendt necessitate the nonhuman animal against which to laud human agency as a capacity for (re)invention as more than mere biological life. Whereas, for Badiou, we find the thinking human in 'an animal whose resistance, unlike that of a horse, lies not in his fragile body', for Arendt, as soon as people are 'forced to live outside the common world', as in concentration camps, 'they begin to belong to the human race in much the same way as animals belong to a specific animal species'. ${ }^{106}$ And yet, as Kelly Oliver has recently argued, there is room for expanding Arendt's philosophy - and, I would add, Badiou's - into nonhuman territory in our uncertain environmental times. Recognising the distinction between Arendt's notion of the human world in contradistinction to the physical Earth, Oliver writes: 'Even if, with Arendt, we separate world and earth by associating world with the human world of meaning and earth with our given physical limitations or animal bodies, 
still both the human world of meaning and our existence on the physical earth are dependent upon not just human diversity but also biodiversity'. ${ }^{107}$

By reinstituting the networks of the physical Earth into the global network, The Human Surge calls to mind what Oliver terms 'earth ethics', which for her 'acts as a counterbalance to globalism insofar as it is grounded on the earth as a dynamic network of relationships through which each and all earthlings share the earth even if they do not share a world'. ${ }^{108}$ She goes on:

This means that individuals, species, and nations are fundamentally interconnected. It means that relationality is primary rather than secondary to who we are and what we can do. It means that if earth is an island, then we must reconceive islands as dynamic spaces constituted by their relationships to air, sea, and the elements that make them what they 'truly are'. In other words, it means that we must embrace the fact that we are limited creatures who are not just living on earth, but rather part of the biosphere that constitutes its very being. ${ }^{109}$

The Human Surge's contribution to this philosophical debate and the global network narrative genre resides both in its refusal to define the human as a suffering body and its resolution to open up the network - one that is as attuned to the phenomenology of being-in-the-world and an unjust world system, as it is to the Earth as the ground and planet we share with other human and nonhuman beings.

107 Kelly Oliver, Earth and World: Philosophy after the Apollo Missions (New York: Columbia University Press, 2015), 91.

108 Ibid., 40, my emphasis.

109 Ibid., 41. 